\title{
PENGARUH SARANA DAN PELAYANAN TERHADAP KEPUASAN MAHASISWA PROGRAM STUDI PENDIDIKAN EKONOMI FAKULTAS PENDIDIKAN ILMU PENGETAHUAN SOSIAL IKIP PGRI BOJONEGORO
}

\author{
Sarjono dan Eka Farida \\ FPIPS, IKIP PGRI Bojonegoro \\ Email: sarjonoikippgribjn@gmail.com \\ FPIPS, IKIP PGRI Bojonegoro \\ Email: feka46@yahoo.com
}

\begin{abstract}
This study aims to determine the effect of facilities and services on student satisfaction Study Program Economic Education Faculty of Education Social Sciences IKIP PGRI Bojonegoro. Procurement of facilities and services starting from the needs of students, so that the success or failure of facilities and services provided can be seen from the perception of students on the quality of facilities and services which is a total assessment of the benefits of facilities and services provided to students. In this case, student satisfaction will be achieved if the quality of facilities and services provided in accordance with the required. The population in this study are the students of Economics Education program level I to IV as much as 402 respondents. Sample taken 10\% with probability sampling technique equal to 40 respondents. Technique of gathering datamenggunakan instrument in the form of kuesioner. Data analysis techniques used multiple regression analysis, hypothesis test ( $F$ test and $t$ test), and test of coefficient of determination. The result of the research shows that the variables of the facilities have a significant effect on the students 'satisfaction, while the service variable has no significant effect on the students' satisfaction. F test results show that the means and services have a significant effect on the satisfaction of the students of Economic Education Study Program of $58.3 \%$ based on the R2 value of 0.583 with the significance of 0.000 .
\end{abstract}

Keywords : Facilities, Service, and Students Satisfaction

\begin{abstract}
Abstrak: Penelitian ini bertujuan untuk mengetahui pengaruh sarana dan pelayanan terhadap kepuasan mahasiswa Program Studi Pendidikan Ekonomi Fakultas Pendidikan Ilmu Pengetahuan Sosial IKIP PGRI Bojonegoro. Pengadaan sarana dan pelayanan dimulai dari kebutuhan mahasiswa, sehingga berhasil atau tidaknya sarana dan layanan yang disediakan dapat dilihat dari persepsi mahasiswa terhadap kualitas sarana dan pelayanan yang merupakan penilaian total atas keunggulan sarana dan pelayanan yang diberikan kepada mahasiswa. Dalam hal ini, kepuasan mahasiswa akan tercapai apabila kualitas sarana dan pelayanan yang disediakan sesuai dengan yang dibutuhkan. Populasi dalam penelitian ini adalah mahasiswa program studi Pendidikan Ekonomi tingkat I s/d IV sebanyak 402 responden. Sampel diambil $10 \%$ dengan teknik probability sampling sebesar 40 responden. Teknik pengumpulan datamenggunakan instrumen berupa kuesioner. Teknik analisis data menggunakan analisis regresi berganda, uji hipotesis (uji F dan uji t), dan uji koefisien determinasi. Hasil penelitian secara parsial menunjukkan variabel sarana berpengaruh signifikan terhadap kepuasan mahasiswa, sedangkan variabel pelayanan tidak berpengaruh signifikan terhadap kepuasan mahasiswa. Hasil Uji F menunjukkan bahwa sarana dan pelayanan berpengaruh signifikan terhadap kepuasan mahasiswa program studi Pendidikan Ekonomi sebesar 58,3\% yang didasarkan pada nilai $\mathrm{R}^{2}$ sebesar 0,583 dengan signifikansi 0,000 .
\end{abstract}

Kata Kunci : Sarana, Pelayanan, dan Kepuasan Mahasiswa 


\section{PENDAHULUAN}

Institusi pendidikan dalam iklim kompetensi dunia pendidikan harus sangat memperhatikan sarana dan kualitas pelayanan yang baik. Hal ini dikarenakan persediaan sarana dan pelayanan yang baik dapat meningkatkan kepuasaan tersendiri bagi mahasiswa sehingga dapat memberikan kenyamanan baik dalam proses belajar mengajar maupun didalam memanfaatkan layanan yang disediakan oleh kampus.

Kepuasan mahasiswa merupakan suatu sikap positif mahasiswa terhadap pelayanan yang diberikan oleh perguruan tinggi karena adanya kesesuaian antara harapan dan kenyataan yang diterima. Sopiatin (2010) menyatakan persepsi mahasiswa terhadap lembaga pendidikan yang dapat menimbulkan kepuasan mahasiswa terdiri atas delapan aspek yaitu kinerja dosen, kinerja universitas, aktifitas mahasiswa, kedisiplinan mahasiswa, peluang membuat keputusan, bangunan universitas, komunikasi dan teman sekitar.

Arikunto (1993:20) menyatakan bahwa kualitas pembelajaran bervariasi sesuai dengan sarana yang digunakan. Semakin lengkap sarana yang digunakan diharapkan semakin berkualitas proses belajarnya dan semakin sedikit sarana yang dipergunakan maka akan semakin rendah pula hasil proses belajarnya. Sehingga sarana belajar merupakan suatu alat yang harus ada atau harus disediakan oleh lembaga pendidikan selama proses belajar. Sedangkan konsep kualitas pelayanan Serqual yang dikembangkan oleh Parasuraman, Berry, dan Zeithml (1988) yang awalnya diformulasikan menjadi 10 dimensi kemudian disederhanakan menjadi lima dimensi, yaitu: (1) tangible (bukti langsung) mencakup fasilitas fisik, perlengkapan, pegawai, dan sarana komunikasi; (2) reliability (reliabilitas), yaitu kemampuan memberikan pelayanan yang dijanjikan dengan segera, akurat, dan memuaskan; (3) responsiveness (daya tanggap), yaitu keinginan staf membantu para pelanggan dan memberikan layanan dengan tanggap; (4) assurance (jaminan), mencakup pengetahuan, kompetensi, kesopananm dan sifat dapat dipercaya yang dimiliki staf, bebas dari bahaya, risiko atau keragu-raguan; (5) emphaty (empati), meliputi kemudahan dalam menjalin relasi, komunikasi yang baik, perhatian pribadi, dan pemahaman atas kebutuhan individu para pelanggan.

Pengadaan sarana dan pelayanan dimulai dari kebutuhan mahasiswa, sehingga berhasil atau tidaknya sarana dan layanan yang disediakan dapat dilihat dari persepsi mahasiswa terhadap kualitas sarana dan pelayanan yang merupakan penilaian total atas keunggulan sarana dan pelayanan yang diberikan kepada mahasiswa. Dalam hal ini, kepuasan mahasiswa akan tercapai apabila kualitas sarana dan pelayanan yang disediakan sesuai dengan yang dibutuhkan.

Tjiptono (2004) menyatakan bahwa perguruan tinggi merupakan salah satu instansi pendidikan, supaya akuntabel dan bermutu dituntut untuk memberikan pelayanan akademik yang berkualitas. Kualitas Sarana dan pelayanan memegang peranan yang sangat penting dalam fungsi pemasaran, karena hal ini akan berpengaruh pada keberlangsungan suatu institusi, dalam hal ini yang dimaksud adalah intitusi pendidikan meliputi perguruan tinggi baik perguruan tinggi negeri maupun swasta, banyak yang terpacu untuk meningkatkan kualitas pendidikan baik dari perbaikan sarana-prasarana, mutu dosen, maupun sistem pelayanan. Jika hal ini tidak dipenuhi, maka akan muncul ketidakpuasan dari mahasiswa sehingga dalam jangka panjang akan menjadi ancaman bagi 
keberlanjutan perguruan tinggi tersebut.

Salah satu perusahaan yang bergerak di bidang jasa khusunya pendidikan adalah perguruan tinggi. Menurut Collier dalam Yamit, (2002:22) Kualitas jasa merupakan kualitas yang lebih menekankan pada kata pelayanan, kualitas, dan level atau tingkat. Persaingan yang sangat ketat antar perguruan tinggi membutuhkan peningkatan baik dalam mutu pelayanan yang ditawarkan, seperti sarana dan prasarana, maupun mutu dan profesionalisme dari dosen. Begitu juga halnya dengan IKIP PGRI Bojonegoro, yang merupakan salah satu perguruan tinggi swasta di Bojonegoro, selain IKIP PGRI Bojonegoro tedapat juga Universitas Bojonegoro (UNIGORO), Universitas Terbuka (UT), POLTEK Negeri Malang yang membuka cabang di daerah Bojonegoro, dalam hal ini mempunyai dampak banyaknya pilihan bagi masyarakat di dalam memilih perguruan tinggi. Keadaan persaingan yang cukup kompetitif antar pegururan tinggi menuntut lembaga pendidikan memperhatikan mutu pendidikan dan kelembagaan sehingga mampu serta unggul dalam persaingan tersebut (Srinadi dan Nilakusmawati, 2008). Oleh sebab itu, setiap perguruan tinggi menawarkan berbagai pelayanan dan keunggulannya.

Program studi pendidikan ekonomi FPIPS IKIP PGRI Bojonegoro merupakan salah satu program studi yang menawarkan jasa pendidikan, sehingga dapat dimanfaatkan oleh mahasiswa dalam menempuh pendidikan strata 1 . Oleh karena itu, dalam proses belajar mengajar program studi pendidikan ekonomi membutuhkan sarana dan pelayanan yang memadai pula. Namun, pada kenyataannya masih ada mahasiswa yang mengeluh atas sarana dan pelayanan yang disediakan oleh kampus, misalnya banyaknya LCD yang rusak sehingga menghambat jalannya proses pembelajaran, selain itu pelayanan yang disediakan seringkali tidak sesuai dengan yang diharapkan. Padahal layanan yang diberikan secara konsisten akan memunculkan suatu ukuran standar mengenai pelayanan yang baik pada suatu perguruan tinggi, sehingga layanan yang diberikan dari segi kualitas harus terus dipertahankan dan apabila dimungkinkan untuk terus meningkatkannya.

Berkaitan dengan paparan di atas maka tujuan dari penelitian ini adalah untuk mengetahui pengaruh sarana dan pelayanan terhadap kepuasan mahasiswa program studi pendidikan ekonomi FPIPS IKIP PGRI Bojonegoro.

\section{METODE PENELITIAN}

Jenis penelitian yang digunakan dalam penelitian ini adalah penelitian asosiatif kuantitatif karena penelitian ini untuk mencari pengaruh variabel bebas terhadap variabel terikat dengan menggunakan data kuantitatif atau angka, karena data yang diperoleh dari populasi penelitian dianalisis sesuai dengan metode statistik yang digunakan kemudian diinterpretasikan.

Arikunto (2010:108), populasi adalah keseluruhan objek penelitian. Populasi dalam penelitian ini adalah mahasiswa program studi pendidikan ekonomi FPIPS IKIP PGRI Bojonegoro sebanyak 402 responden. Penentuan sampel dalam penelitian ini menggunakan teknik probability sampling. Adapun cara yang digunakan adalah stratified random sampling, dimana sampel diambil sebanyak $10 \%$ dari mahsiswa tingkat I s/d tingkat IV. Berdasarkan teknik tersebut, maka jumlah sampel dalam penelitian sebanyak 40 responden.

Instrumen yang digunakan dalam teknik pengumpulan data adalah kuesioner 
yang disebarkan kepada para responden untuk mengukur sarana, layanan, dan kepuasan mahasiswa. Kuesioner disusun berdasarkan skala Likert yang terdiri dari lima skala.

Waktu yang dibutuhkan peneliti untuk mengumpulkan data adalah 2 (dua) bulan terhitung mulai tanggal 14 September
- 23 November 2017. Dalam penelitian ini analisis data yang digunakan adalah analisis deskriptif, analisis regresi berganda, uji hipotesis, dan koefisien determinasi. Untuk melakukan analisis data tersebut menggunakan bantuan program SPSS for Windows versi 16.0.

\section{HASIL DAN PEMBAHASAN}

\section{Statistik Deskriptif}

Tabel 1 Descriptive Statistics

\begin{tabular}{|l|r|r|r|r|r|}
\hline & $\mathrm{N}$ & Min & Max & Mean & $\begin{array}{c}\text { Std. } \\
\text { Deviation }\end{array}$ \\
\hline Sarana & 40 & 18 & 38 & 32.07 & 4.227 \\
Pelayanan & 40 & 14 & 33 & 27.80 & 4.090 \\
Kepuasan & 40 & 17 & 49 & 37.58 & 6.943 \\
Valid N & 40 & & & & \\
(listwise) & & & & & \\
\hline
\end{tabular}

Berdasarkan tabel di atas diperoleh data sebagai berikut.

\section{Kepuasan Mahasiswa}

Dari hasil pengujian statistik deskriptif, rata-rata kepuasan mahasiswa program studi pendidikan ekonomi FPIPS IKIP PGRI Bojonegoro pada tahun yang diamati adalah 37,58. Dimana standar deviasinya adalah 6,943, dengan nilai minimum 17 dan maksimum 49. Dapat dilihat bahwa rata-rata kepuasan mahasiswa program studi pendidikan ekonomi cukup tinggi, hal ini menunjukkan bahwa mahasiswa merasakan kenyamanan dalam mengambil studi di program studi pendidikan ekonomi FPIPS IKIP PGRI Bojonegoro.

\section{Sarana}

Dari hasil uji statistik deskriptif, dapat disimpulkan bahwa rata-rata sarana yang dapat dimanfaatkan mahasiswa IKIP PGRI Bojonegoro adalah 32,07 dengan standar deviasi 4,227. Dengan nilai maksimum sebesar 38 dan nilai minimum sebesar 18. Melihat cukup tingginya angka rata-rata sarana ini dapat berarti bahwa sarana yang disediakan oleh kampus dapat langsung dirasakan manfaatnya oleh mahasiswa program studi pendidikan ekonomi FPIPS IKIP PGRI Bojonegoro. Oleh karena itu ketersediaan sarana dapat memenuhi kebutuhan mahasiswa dalam proses pelaksanaan pembelajaran sebagai tahap penyelesaian pendidikan.

\section{Pelayanan}

Berdasarkan hasil pengujian statistik deskriptif, rata-rata pelayanan yang dirasakan oleh mahasiswa sudah baik dan sesuai dengan yang diharapkan mahasiswa program studi pendidikan ekonomi FPIPS IKIP PGRI Bojonegoro. Baiknya nilai pelayanan ditunjukkan dari besarnya nilai rata-rata pelayanan 27,80 dengan standar deviasi 4,090, nilai maksimum sebesar 33 sedangkan nilai minimum sebesar 14 . 


\section{Gambaran Umum Obyek Penelitian}

Pengumpulan data pada penelitian ini menggunakan instrumen kuesioner. Responden dalam penelitian ini adalah mahasiswa tingkat I sampai tingkat IV program studi pendidikan ekonomi FPIPS IKIP PGRI Bojonegoro. Jumlah keseluruhan kuesioner sebanyak 40.

Hasil penelitian ini dianalisis secara deskriptif dan kuantitatif. Analisis deskriptif dilakukan dengan cara mendeskripsikan setiap butir pernyataan, yang bertujuan untuk memperoleh gambaran mengenai variabel-variabel yang diteliti. Sedangkan analisis kuantitatif dilakukan dengan formula statistika yakni mencakup koefisien korelasi, koefisien determinasi, dan regresi. Tujuannya adalah untuk mengetahui seberapa kuat pengaruh dan besarnya kontribusi variabel bebas terhadap variabel terikat.

Sampel yang diuji adalah mahasiswa tingkat I sampai tingkat IV program studi Pendidikan Ekonomi IKIP PGRI Bojonegoro. Dari 40 responden yang dijadikan sampel dalam penelitian ini, dapat disajikan deskripsi data responden berdasarkan jenis kelamin, tingkat kelas, dan alamat rumahnya.

\section{Profil Responden Berdasarkan Jenis Kelamin}

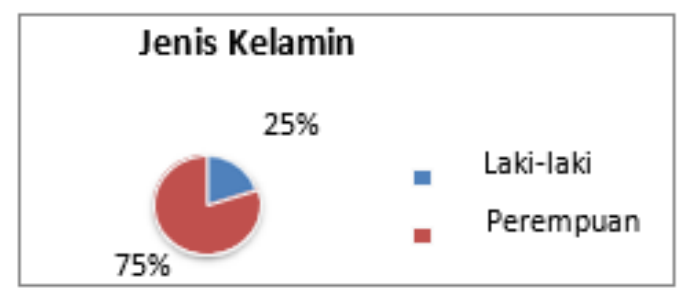

Gambar 1 Responden Berdasarkan Jenis Kelamin

Profil responden berdasarkan jenis kelamin diperlihatkan pada Gambar 1 dari 40 responden yang terlibat dalam penelitian ini, mayoritas responden berjenis kelamin perempuan yaitu dengan jumlah sebanyak 30 responden atau dengan mendapatkan nilai persentasi sebesar $75 \%$. Sedangkan sisanya adalah responden yang berjenis kelamin laki-laki yaitu dengan jumlah sebanyak 10 responden atau nilai presentasinya sebesar $25 \%$.

\section{Profil Responden Berdasarkan Tingkat Kelas}

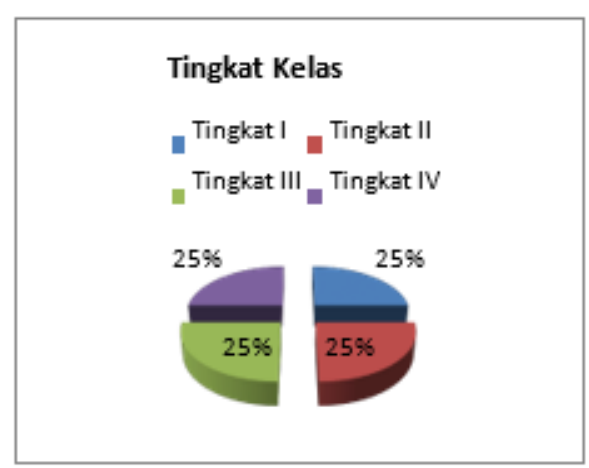

Gambar 2 Responden Berdasarkan Tingkat Kelas 
Profil responden berdasarkan tingkat kelas diperlihatkan pada Gambar 2 dari 40 responden yang terlibat dalam penelitian ini, semua tersebar rata mulai dari responden atau mahasiswa tingkat I sampai mahasiswa tingkat IV, dari tingkat I diambil 10 responden dengan nilai persentasi sebesar $25 \%$, tingkat II diambil 10 responden dengan nilai persentasi sebesar 25\%, tingkat III diambil 10 responden dengan nilai persentasi sebesar $25 \%$, dan dari tingkat IV juga diambil 10 responden dengan nilai persentasi sebesar $25 \%$.

\section{Profil Responden Berdasarkan Alamat Rumah}

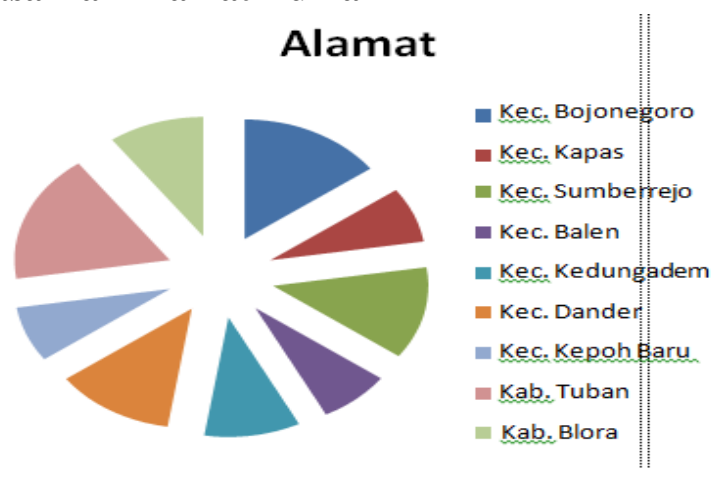

Gambar 3 Responden Berdasarkan Alamat Rumah

Profil responden berdasarkan alamat rumah diperlihatkan pada Gambar 3 dari 40 responden yang terlibat dalam penelitian ini, terdapat 6 responden tinggal di kecamatan Bojonegoro dengan nilai persentase sebesar 15\%, 3 responden tinggal di kecamatan Kapas dengan nilai persentase sebesar 7,5\%, 5 responden tinggal di kecamatan Sumberrejo dengan nilai persentase sebesar $12,5 \%, 3$ responden tinggal di kecamatan Balen dengan nilai persentase sebesar $7,5 \%, 4$ responden tinggal di kecamatan Kedungadem dengan nilai persentase sebesar 10\%, 5 responden tinggal di kecamatan Dander dengan nilai persentase sebesar 12,5\%, 3 responden tinggal di kecamatan Kepoh Baru dengan nilai persentase sebesar 7,5\%,7 responden tinggal di kabupaten Tuban dengan nilai persentase $17,5 \%$, dan 4 responden tinggal di kabupaten Blora dengan nilai persentase sebesar $10 \%$.

\section{Hasil Analisis Regresi Berganda}

Model analisis regresi berganda digunakan untuk mengetahui pengaruh sarana dan pelayanan terhadap kepuasan mahasiswa. Rangkuman hasil analisis dapat dilihat pada tabel berikut ini.

Tabel 2 Rangkuman Hasil Uji Regresi Berganda

\begin{tabular}{|l|c|c|}
\hline \multirow{2}{*}{ Model } & \multicolumn{2}{|c|}{$\begin{array}{c}\text { Unstandardized } \\
\text { Coefficients }\end{array}$} \\
\cline { 2 - 3 } & B & Std. Error \\
\hline Konstan & 0,548 & 8,237 \\
\hline Sarana & 1,236 & 0,177 \\
\hline Pelayanan & $-0,094$ & 0,183 \\
\hline
\end{tabular}


Berdasarkan tabel hasil rangkuman analisis data di atas dapat disusun persamaan regresi sebagai berikut. $Y=0,548+1,236 X 1-0,094 X 2$

Dari persamaan regresi di atas kontanta sebesar 0,548, dengan nilai koefisien regresi $X_{1}$ sebesar 1,236, dan nilai koefisien regresi $X_{2}$ sebesar $-0,094$, hal ini menunjukkan bahwa:

1) Nilai konstanta sebesar 0,548 menunjukkan bahwa jika tidak dipengaruhi oleh variabel sarana dan pelayanan maka dimensi kepuasan mahasiswa sebesar 0,548.

2) Nilai koefisien variabel $X_{1}$ (Sarana) sebesar 1,236 menunjukkan bahwa jika dimensi sarana bertambah satu satuan maka kepuasan mahasiswa akan naik sebesar 1,236.

3) Nilai koefisien variabel $X_{2}$ (pelayanan) sebesar - 0,094 menunjukkan bahwa jika dimensi pelayanan berkurang satu satuan maka kepuasan mahasiswa akan turun sebesar 0,094.

\section{Uji Hipotesis}

Uji F

Tabel 3 Uji F/Anova

ANOVA $^{b}$

\begin{tabular}{|c|c|c|c|c|c|}
\hline Model & $\begin{array}{c}\text { Sum of } \\
\text { Squares }\end{array}$ & Df & $\begin{array}{c}\text { Mean } \\
\text { Squar } \\
\mathbf{e}\end{array}$ & $\mathbf{F}$ & Sig. \\
\hline $\begin{array}{ll}1 & \text { Regression } \\
& \text { Residual } \\
& \text { Total } \\
\end{array}$ & $\begin{array}{l}1095.069 \\
784.706 \\
1879.775\end{array}$ & $\begin{array}{l}2 \\
37 \\
39\end{array}$ & $\begin{array}{l}547.535 \\
21.208\end{array}$ & 25.817 & $.000^{\mathrm{a}}$ \\
\hline \multicolumn{6}{|c|}{$\begin{array}{l}\text { a. Predictors:(Constant), pelayanan, sarana } \\
\text { b. Dependent Variable: kepuasan }\end{array}$} \\
\hline
\end{tabular}

Hasil perhitungan menunjukkan nilai $\mathrm{F}_{\text {hitung }}=25,817 . \quad \mathrm{F}_{\text {tabel}}$, pada tingkat signifikansi 0,05 dengan df 1 adalah (jumlah variabel - 1) $=2$, dan df $2(\mathrm{n}-\mathrm{k}-1)$ atau $(40-2-1)=37$ dimana $n$ adalah jumlah data dan $\mathrm{k}$ adalah jumlah variabel. Hasil yang diperoleh adalah 3,250, sehingga $\mathrm{F}_{\text {hitung }}>\mathrm{F}_{\text {tabel, }}$ yang berarti $\mathrm{Ha}$ diterima. Tabel 3 uji anova juga menunjukkan tingkat signifikansi 0,000 yaitu lebih kecil dari nilai $\alpha=0,05$ sehingga Ha diterima artinya secara simultan sarana dan pelayanan berpengaruh signifikan terhadap kepuasan mahasiswa program studi Pendidikan Ekonomi FPIPS IKIP PGRI Bojonegoro.

\section{Uji t (Parsial)}

Uji t dimaksudkan untuk mengetahui pengaruh masing-masing $X_{1}$ (sarana) dan $\mathrm{X}_{2}$ (pelayanan) tehadap $\mathrm{Y}$ (kepuasan mahasiswa). Derajat kebebasan $\mathrm{df}=\mathrm{n}-\mathrm{k}-$ 1 dimana $n$ adalah jumlah sampel/data dan $\mathrm{k}$ adalah jumlah variabel independen, sehingga $\mathrm{df}=40-2-1=37$ pada signifikansi 0,05 . Hasil yang diperoleh untuk tabel adalah 1,687. Setelah diperoleh hasil $t_{\text {tabel }} \mathrm{di}$ atas dan berdasarkan pada hasil output SPSS mengenai uji t, maka:

a) Hasil thitung untuk variabel $\mathrm{X}_{1}$ (sarana) $=$ 6,989 dan $t_{\text {tabel }}=1,687$. Karena $t_{\text {hitung }}>$ $\mathrm{t}_{\text {tabel }}$ maka $\mathrm{H}_{\mathrm{a}}$ diterima. Atau dapat juga dilihat signifikan t sebesar 0,000 , lebih kecil dari 0,05 ini menunjukkan bahwa 
$\mathrm{H}_{\mathrm{a}}$ diterima. Artinya variabel sarana berpengaruh secara signifikan terhadap kepuasan mahasiswa program studi Pendidikan Ekonomi FPIPS IKIP PGRIBojonegoro.

b) Hasil thitung untuk variabel $\mathrm{X}_{2}$ (pelayanan) $=-514$ dan $t_{\text {tabel }}=1,687$. Karena $t_{\text {hitung }}<\mathrm{t}_{\text {tabel }}$ maka $\mathrm{H}_{0}$ diterima. Dengan signifikan $\mathrm{t}$ sebesar 0,611 . Artinya variabel pelayanan tidak berpengaruh signifikan terhadap kepuasan mahasiswa program studi Pendidikan Ekonomi FPIPS IKIP PGRI Bojonegoro.

\section{Koefisien Determinasi}

Untuk mengetahui besarnya nilai koefisien determinasi ditunjukkan oleh nilai $R$ Square. Berkut ini adalah hasil perhitungan koefisien determinasi:

Tabel 4 Nilai Koefisien Determinasi

Model Summary ${ }^{b}$

\begin{tabular}{|l|r|r|r|r|l|}
\hline Model & \multicolumn{1}{|c|}{$\mathrm{R}$} & $\begin{array}{c}\mathrm{R} \\
\text { Square }\end{array}$ & Adjusted R Square & $\begin{array}{c}\text { Std. Error of the } \\
\text { Estimate }\end{array}$ & \multicolumn{1}{l|}{ Durbin- Watson } \\
\hline 1 & .763 & .583 & .560 & 4.60524 & 1.649 \\
& $\mathrm{a}$ & & & & \\
\hline
\end{tabular}

Berdasarkan tabel di atas, dapat diketahui bahwa nilai $R$ Square yaitu sebesar 0,583 yang menunjukkan bahwa sarana dan pelayanan berpengaruh terhadap kepuasan mahasiswa program studi Pendidikan Ekonomi FPIPS IKIP PGRI Bojonegoro sebesar 58,3\%, sedangkan sisanya dipengaruhi oleh variabel lain diluar penelitian ini.

\section{Pengaruh Sarana terhadap \\ Kepuasan Mahasiswa}

Berdasarkan hasil pengujian hipotesis secara parsial diperoleh hasil variabel $\mathrm{X}_{1}$ (sarana) memiliki koefisien regresi sebesar 1,236, thitung sebesar 6,989, $t_{\text {tabel }}$ sebesar 1,687 dan nilai signifikansi 0,000. Artinya jika sarana naik satu satuan maka kepuasan mahasiswa naik 1,236. Jadi, produsen dalam hal ini pihak kampus harus mengoptimalkan kuantitas dan kualitas demi meningkatkan kepuasan mahasiswa. Karena $t_{\text {hitung }}>t_{\text {tabel }}$ dan nilai signifikansi di bawah 0,05 maka variabel $\mathrm{X}_{1}$ (sarana) berpengaruh secara signifikan terhadap variabel Y (kepuasan mahasiswa).

Jadi, hasil dari penelitian ini menunjukkan bahwa sarana berpengaruh signifikan terhadap kepuasan mahasiswa program studi Pendidikan Ekonomi FPIPS IKIP PGRI Bojonegoro.

\section{Pengaruh Pelayanan Terhadap Kepuasan Mahasiswa}

Berdasarkan hasil pengujian hipotesis secara parsial diperoleh hasil variabel $\mathrm{X}_{2}$ (pelayanan) memiliki koefisien regresi sebesar $-0,094$, $t_{\text {hitung }}$ sebesar $0,514, \mathrm{t}_{\text {tabel }}$ sebesar 1,687 dan nilai signifikansi sebesar 0,611. Jadi, karena $\mathrm{t}_{\text {hitung }}<\mathrm{t}_{\text {tabel }}$ dan nilai signifikansi di atas 0,05 , maka variabel $X_{2}$ (pelayanan) tidak berpengaruh terhadap variabel Y (kepuasan mahasiswa). Jika produsen atau pihak kampus tidak memperhatikan mengenai kualitas pelayanan yang diberikan maka akan terjadi penurunan sebesar 0,094. Oleh sebab itu, produsen atau pihak kampus harus meningkatkan kualitas dalam 
pelayanan agar konsumen atau mahasiswa IKIP PGRI Bojonegoro merasa puas dan nyaman dalam memanfaatkan seluruh fasilitas atau pelayanan yang disediakan oleh kampus. Hasil dari penelitian ini menunjukkan bahwa pelayanan tidak berpengaruh signifikan terhadap kepuasan mahasiswa.

\section{Pengaruh Sarana dan Pelayanan Terhadap Kepuasan Mahasiswa Secara Simultan}

Berdasarkan hasil pengujian hipotesis secara simultan yang dapat dilihat pada tabel, maka diperoleh $F_{\text {hitung }}=25,817$, $\mathrm{F}_{\text {tabel }}=3,250$, dan tingkat signifkansi adalah 0,000. Karena $F_{\text {hitung }}>F_{\text {tabel }}$ dan tingkat signifikansinya di bawah 0,05 , maka sarana dan pelayanan secara bersama-sama berpengaruh signifikan terhadap kepuasan mahasiswa program studi pendidikan ekonomi FPIPS IKIP PGRI Bojonegoro.

\section{SIMPULAN}

1. Variabel sarana berpengaruh signifikan terhadap kepuasan mahasiswa karena nilai thitung sebesar 6,989 lebih besar dari pada nilai $t_{\text {tabel }}$ sebesar 1,687 dengan tingkat signifikansi 0,000 yang lebih kecil dari 0,05, maka Ho ditolak.

2. Variabel pelayanan tidak berpengaruh terhadap kepuasan mahasiswa karena

\section{DAFTAR RUJUKAN}

Arikunto, S. (1993). Penilaian Program Pendidikan. Jakarta: Bumi Aksara.

Arikunto, Suharsimi. (2010). Prosedur Penelitian Suatu Pendekatan Praktek (edisi revisi). Jakarta: Rineka Cipta.

Parasuraman, A., Zeithaml, V.A., \& Berry, L. (1988). SERVQUAL: A MultipleItem Scale for Measuring Consumer Perception of Service Quality. nilai $t_{\text {hitung }}$ sebesar $-0,942$ lebih kecil dari pada nilai $t_{\text {tabel }}$ sebesar 1,687 dengan tingkat signifikansi 0,611 yang lebih besar dari 0,05, maka Ho diterima.

3. Variabel sarana dan pelayanan secara bersama-sama berpengaruh terhadap kepuasan mahasiswa karena $F_{\text {hitung }}$ sebesar 25,817 lebih besar dari $\mathrm{F}_{\text {tabel }}$ sebesar 3,250 dengan tingkat signifikansi sebesar 0,000 maka Ho ditolak.

\section{SARAN}

Bagi pihak kampus IKIP PGRI Bojonegoro harus lebih ditingkatkan lagi dalam hal pelayanan kepada seluruh mahasiswa, baik dalam hal keramahan penyampaian tentang administrasi akademik maupun pelayanan-pelayanan lain yang berhubungan langsung dengan mahasiswa sehingga mahasiwa sebagai konsumen merasa nyaman dalam menyelesaikan studinya. Dan mahasiswa harus lebih berhati-hati dalam memanfaatkan sarana yang telah disediakan oleh kampus dan selalu menjaganya dengan baik. Selain itu, sebagai mahasiswa yang cerdas harus mampu memanfaatkan pelayanan yang disediakan dengan bijaksana.

Journal of Retailing, Vol. 64 No. 1, 12-14.

Sopiatin, Popi. (2010). Manajemen Belajar Berbasis Kepuasan Mahasiswa. Bogor: Ghalia Indonesia.

Srinadi dan Nilakusmawati. (2008). "Faktor-Faktor Penentu Kepuasan Mahasiswa Terhadap Pelayanan Fakultas Sebagai Lembaga 
Pendidikan (Studi Kasus di FMIP, Universitas Udayana)" Jurnal Cakrawala Pendidikan. November. Th. XXVII.

Tjiptono, Fandy. (2004). Manajemen Jasa. Yogyakarta: Andi Offset.
Yamit, Z. (2002). Manajemen Kualitas Produk dan Jasa. Edisi Pertama. Yogyakarta: Ekonisia Kampus Fakultas Ekonomi UII. 